\title{
The impact of digital divide for first-year students in adoption of social media for learning in South Africa
}

\begin{tabular}{|c|c|}
\hline \multicolumn{2}{|c|}{$\begin{array}{l}\text { Authors: } \\
\text { Mohube I. Mphahlele }{ }^{1} \\
\text { Sello N. Mokwena } \\
\text { Appolonia Ilorah }{ }^{3}\end{array}$} \\
\hline \multicolumn{2}{|c|}{$\begin{array}{l}\text { Affiliations: } \\
{ }^{1} \text { Department of End User } \\
\text { Computing, Faculty of } \\
\text { Information and } \\
\text { Communication Technology, } \\
\text { Tshwane University of } \\
\text { Technology, Pretoria, } \\
\text { South Africa }\end{array}$} \\
\hline $\begin{array}{l}{ }^{2} \text { Department } \\
\text { Science, Facul } \\
\text { and Agricultur } \\
\text { of Limpopo, S } \\
\text { South Africa }\end{array}$ & $\begin{array}{l}\text { of Computer } \\
\text { ty of Science } \\
\text { e, University } \\
\text { ovenga, }\end{array}$ \\
\hline \multicolumn{2}{|c|}{$\begin{array}{l}{ }^{3} \text { Department of Computer } \\
\text { Science, Faculty of } \\
\text { Information and } \\
\text { Communication Technology, } \\
\text { Tshwane University of } \\
\text { Technology, Polokwane, } \\
\text { South Africa }\end{array}$} \\
\hline \multicolumn{2}{|c|}{$\begin{array}{l}\text { Corresponding author: } \\
\text { Mohube Mphahlele, } \\
\text { mphahlelemi1@tut.ac.za }\end{array}$} \\
\hline \multicolumn{2}{|c|}{$\begin{array}{l}\text { Dates: } \\
\text { Received: } 04 \text { Nov. } 2020 \\
\text { Accepted: } 07 \text { May } 2021 \\
\text { Published: } 19 \text { Aug. } 2021\end{array}$} \\
\hline \multicolumn{2}{|c|}{$\begin{array}{l}\text { How to cite this article: } \\
\text { Mphahlele, M.I., Mokwena, } \\
\text { S.N. \& Ilorah, A., 2021, 'The } \\
\text { impact of digital divide } \\
\text { for first-year students } \\
\text { in adoption of social media } \\
\text { for learning in South } \\
\text { Africa', South African } \\
\text { Journal of Information } \\
\text { Management 23(1), a1344. } \\
\text { https://doi.org/10.4102/ } \\
\text { sajim.v23i1.1344 }\end{array}$} \\
\hline \multicolumn{2}{|l|}{ Read online: } \\
\hline 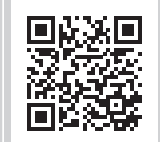 & $\begin{array}{l}\text { Scan this QR } \\
\text { code with your } \\
\text { smart phone or } \\
\text { mobile device } \\
\text { to read online. }\end{array}$ \\
\hline
\end{tabular}

Background: Social media comprise technologies that facilitate learning in higher education institutions. However, many first-year students at tertiary education institutions are not taking advantage of social media for their learning because of environmental and personal factors related to the digital divide (DD).

Objectives: The objective of this research study was to investigate the impact of the DD factors on first-year students in using social media for learning in tertiary education institutions.

Method: A survey method was used to conduct the study. Social cognitive theory was employed as a theory underpinning this research. A questionnaire technique was used to collect data from 600 first-year students of a multi-campus university. Three hundred students came from each of the two campuses. Regression analysis was performed with the purpose of testing the hypotheses of the study.

Results: The result of the analysis revealed a low computer access and usage but a high percentage of mobile devices usage by students from disadvantaged backgrounds. Personal factors were found to have an impact on the behaviour of students in adopting social media for their studies. The study also found that the prevalence of social media nullifies the lack of computer resources and connection to the Internet in disadvantaged areas.

Conclusion: This study demonstrated that the DD was more complex than hitherto envisaged. The study recommends that ownership of computers and devices connected to the Internet needs to be promoted, especially in disadvantaged areas.

Keywords: digital-divide; social media-economic; information and communication technology; first-year students; Facebook; Twitter; YouTube; social media; social status; rural areas.

\section{Introduction}

Information and Communication Technology (ICT) has become an integral part of our economic, political, and social lives, altering the way we purchase goods, bank, communicate with one another and support our education (Ali 2011:211). Social media is one of the ICTs easily adopted and used by the younger generation for socialising. Researchers, such as Kausar and Awan (2019:120), defined social media as a means of communication, collaboration, sharing and exchanging of data through different networks. Social media has numerous benefits, such as the ability to promote and encourage higher public participation in innovations, collaboration and interaction (Haryanti \& Rusfian 2018:131). Most students from the disadvantaged background are not able to benefit from the advantages offered by social media because of the digital divide (DD). Digital divide is defined as the gap between individuals, households, businesses and geographical areas at different socioeconomic levels with regards to their opportunities to access ICT and to their use of the Internet for a wide variety of activities (Organization for Economic Co-operation and Development 2001).

The problem identified in this study is that despite the benefits of using social media technologies for learning, many students are still not adopting this for their learning because of various factors of the DD. The objective of this study was to investigate the impact of the DD on first-year students in using social media for learning in tertiary education institutions. The study was required to answer this research problem: '[w]hy are many students in higher education (HE) institutions still not adopting social media technologies for their studies, despite the benefits offered by social media?' 
This study is deemed to be important because of rampant low level of academic performance in various universities of technology, despite the benefits afforded by e-learning and social media for learning. Because of this low level of academic performance, universities are laying several measures to get the learning materials to students using different digital formats, such as e-Tutors, Social media and Blackboard, and hence, there is a need to determine the factors that may prevent students from using these technologies and the impact of personal and environmental factors on students' learning.

This article is organised as follows: first, the introduction, background, related study and literature, theoretical framework, materials and methods, ethical considerations and references. The article also covers the theory underpinned in this study, materials and methods used, and finally, highlights the findings and recommendation suggested for this study.

\section{Background}

According to Chawinga (2017:6), the use of social media improves blended learning, which helps students to create positive contextual learning in relation to educational intentions. The application of ICT creates more efficient and effective ways for students to become proactive and competitive in the higher institution of learning (Attuquayefio 2019:117). All these opportunities are eluding the first-year students from mostly poor rural areas with no prior access to computers and ICTs. In the same view, Ilorah et al. (2017:252) explained that many rural areas are resource challenged in several ways from a lack of basic ICT infrastructure, electricity to poor network connections.

Development Support Monitor paper revealed that the affordability of ICT devices is low in all provinces of South Africa when compared with other countries. Six years later, Gillwald, Mothobi and Rademan (2018:6) stated that as much as unaffordability of devices is the primary barrier to South Africans coming online, the unaffordability of data is also one of the major factors limiting the intensity of use. Although technology is growing fast day by day and the prices of computers and other ICT devices are not as expensive as before, some families still have difficulties affording and accessing them (Smith 2015). Smith further argued that families who cannot afford Internet access are at a disadvantage compared with those who do.

According to Naidoo and Raju (2012:34), students from HE institutions in South Africa fall into two categories: some with no access or skills, whilst there are others who have had access and are skilled in using and have a vast experience with ICTs. Some students from disadvantaged backgrounds have never used the Internet.

A research study conducted by Beger and Sinha (2012) shows that there is a pronounced DD in South Africa with regards to ICTs' ownership and access, and this is still the situation as indicated by Gillwald et al. (2018). Beger and Sinha went on to define '[d]igital divide' as the gap between those who have access to ICT resources and those who do not have access. Although technology is improving, the DD still exists, thus creating a negative impact on students' learning capabilities

Bala (2018:369) emphasised that the access and use of ICT improve teaching and learning capabilities amongst students and provides real opportunities for individualisation of instruction. However, Naidoo and Raju (2012:34) indicated that majority of the students who enroll in HE institutions only get to use computers and Internet for the first time, and hence, have difficulties even in performing the most basic computer skills.

According to Barnard and Van der Merwe (2015), much as students might have access to Internet, computers and other ICT resources whilst at school, their socio-economic backgrounds limit this access at home. In the same vein, Gudmundsdottir (2010:85) stated that although students access ICT at schools, their access to and use of the same technology at home can be adversely or positively affected by their individual circumstances. As ICT plays a greater role across our society, including public and private education, more countries are more than ever in need of high-quality, internationally comparable statistics on ICT in education (Du Toit 2015:4).

\section{Related work Digital divide}

The term DD is a term that is becoming more complex to define because of the prevalence of social media. Digital divide refers to the gap between people who do and do not have access to various forms of ICT, such as computers, Internet and other ICT resources (Van Duk 2017). This gap could stretch across certain countries that differ in their degree of development, or it could exist between people from the same country who find themselves in different financial, social, educational, geographical and other situations or stages of development (Barnard \& Van der Merwe 2015). The Organization for Economic Co-operation and Development (OECD 2001) defined DD as follows:

[T] ]he gap between individuals, households, businesses, and geographic areas at different socio-economic levels with regards to their opportunities to access information and communication technologies and to their use of the Internet for a wide variety of activities. (p. 5)

This definition by OECD is adopted in this study. According to Sparks (2013:28), DD covers a broad range of social, economic and geographical differences in access to and use of digital equipment and services. Sparks further explains that these differences (social, economic and geographical) are most notably personal computers, and the ability to access the Internet in terms of both physical connection and facility of use. 
Digital divide comes in different forms, such as; those which is located on an international level, that is, between different countries, such as developed and developing countries, or located at an intra-national level, or within a country, such as rural or urban or DD between individuals with different levels of socio-economic factors (Cruz-Jesus, Oliveira \& Bacao 2012:279). Haight, Quan-Haase and Corbett (2014:506) found, in their study of Canadian society, that differences in access to ICTs exist between those with low income, rural or urban dwellers, low education and immigration status. Learners coming from families with high incomes, far-reaching and influential social relationships and high skills have a greater affinity for using digital tools when compared with those from low- or middle-income families (Krish et al. 2018:2).

This study focuses on the DD amongst individuals with different levels of socio-economic factors.

Socio-economic factors are the social and economic experiences and realities that help in developing one's personality, attitudes and lifestyle (Chase 2017). Chase further explained that socio-economic factors include education, income and occupation, place of residence and culture or ethnicity. Chetty et al. (2018:2) identified that families from low- or middle-income groups have a limited access to digital technologies, such as computers, internet and ICT resources, because of high cost and lack of infrastructure. Camerini, Schulz and Jeannet (2018:2491) supported the statement by explaining that not only do people from the lower socio-economic status (SES) not have access to such technologies but also they lack knowledge on how to access these technologies. The DD has impacted the society socially, economically and technologically.

\section{Access of information and communication technologies in South Africa}

Information and communication technologies are a very important aspect for socialising and can also be used for shopping, banking, communicating and supporting our education. Despite the growing use of ICTs, members of the society have different levels of accessing ICTs (Soh et al. 2012:75). Accessing ICTs is sometimes very challenging, not only to community members but also to students. Broadbent and Papadopoulos (2013:5) indicated that it is very important for students to have access to and use of ICTs at schools for their learning because it contributes much to the economy. According to Gemiya (2020:51), developing countries, such as South Africa, find it difficult to enjoy life and improve their economy because of limited internet access and shortage of ICT accessibility.

\section{Impact of digital divide in students' education}

Our educational system is on a higher demand to adopt and integrate ICT tools and techniques into teaching and learning processes (Esfijani \& Zamani 2020:1). Social support from both schools and parents are influential factors impacting the access and use of ICT by students (Li \& Ranieri 2013:198). Socio-economic circumstances also play a significant role in ICT access. Students may have access to technology (computers, telephones, etc.) whilst on campus, but do not have access to these technologies off campus (Barnard \& Van der Merwe 2015). Despite ICT access at school, individual differences and home access can affect learners' use and skills (Gudmundsdottir 2010). The study of Gudmundsdottir (2010) indicated that socio-economic differences, location and language affect learners' opportunities and appetite to use ICT within and outside of schools.

The study of Naidoo and Raju (2012:38) on the impact of DD in information literacy training revealed that of 224 students who indicated their level of ICT experience, 148 (66\%) had little or no ICT experience when they first came to the Durban University of Technology. Another study conducted by Gündüz (2010:48) on DD in Turkish primary schools revealed that a very few of the students who come from families of low socio-economic level have computers at home when compared with those who come from the middle socioeconomic level families, and almost all of the students who come from higher socio-economic families have computer in their homes.

Another study of Vekiri (2010) found that there were significant differences amongst students by SES in accessing and using computers and the Internet outside schools and home, as well as in the nature and variety of their computer activities. This shows that students from low-SES backgrounds were at a disadvantage compared with those from the other SES groups. The study from Pew Research Center revealed that $78 \%$ of those living in the highestincome households use social media compared with $56 \%$ of those living in the lowest-income households (Perrin 2015).

\section{Social media for learning}

Social media refers to web-based and mobile application that allows individuals and organisations to create, engage and share a new user-generated or existing content in digital environments through multi-way communication (Davis et al. 2012). Social media encourage students to create relationship, provide them a collaborative environment to communicate with teachers and help them to create groups using social media learning tools so that the connection of students with their university will more likely improve their learning skills and to persist and complete their education (Hassan et al. 2019). Social media technologies, as demonstrated by Arif and Kanwal (2016), were found to be an effective means of communication in the HE institutions.

\section{Facebook}

Facebook, as suggested by Tiryakioglu and Erzurum (2011:136), is the largest social media network with the biggest audience compared with other social media technologies, particularly because it enables people to effectively communicate with their friends and conveniently 
exchange multimedia-based information. Facebook, as speculated by Singh (2018:141), is a profile-based site that simplifies the communication flow between users of the system through the content posted on the user's personal page. He further explains that students can connect with their lecturers using Facebook. As suggested by Prescott, Wilson and Becket (2013), Facebook has been viewed as a good tool for encouraging peer support and informal learning between students, such as increased communication and support on course content and assessments

\section{Twitter}

Twitter, as explained by Singh (2018:145), is a friendly networking site that allows the user to broadcast and receive messages from a smartphone, laptop, desktop, tablet or iPad and more. He further speculates that many institutions use it for educational interactions and up-to-date activities for students, teachers and administration. Educators who have developed a strong personal learning network on Twitter have access to the most recent information on any topic imaginable (Chamberlin \& Lehmann 2011). The study carried out by Junco, Heibergert and Loken (2011:126) on college students' engagement using Twitter revealed that Twitter allowed them to extend their conversations in ways that would not have been practical during the hour-long class sessions.

\section{YouTube}

YouTube is an example of social media that allows for the development of social relationships that revolves around uploaded videos (Moghavvemi et al. 2018:38). It was confirmed that YouTube is used by a large number of students for learning through videos. It has a dedicated, special channel for education called TeacherTube for teachers to upload their instructional materials and share with other educators (Liu 2010:112). There are evidences in education that YouTube has been used for the following purposes (Liu 2010:112): class videos have been provided for flexible learning amongst students, videos used as a visual aid to help students to better understand the course content, videos used to address different student learning styles and videos used as research resources.

\section{Theoretical background}

Theories and models are significant in directing the research process (Mokwena \& Hlebela 2018). The study employed social cognitive theory developed by Bandura (1986) to investigate how the DD impact the adoption of social media for learning, because according to this theory, people are neither driven by inner forces nor automatically shaped and controlled by the environment (Bandura 1989).

The model is conceptualised to suit this research study. In the conceptualised model, personal and environmental factors influence each other, and they both affect the behaviour of the

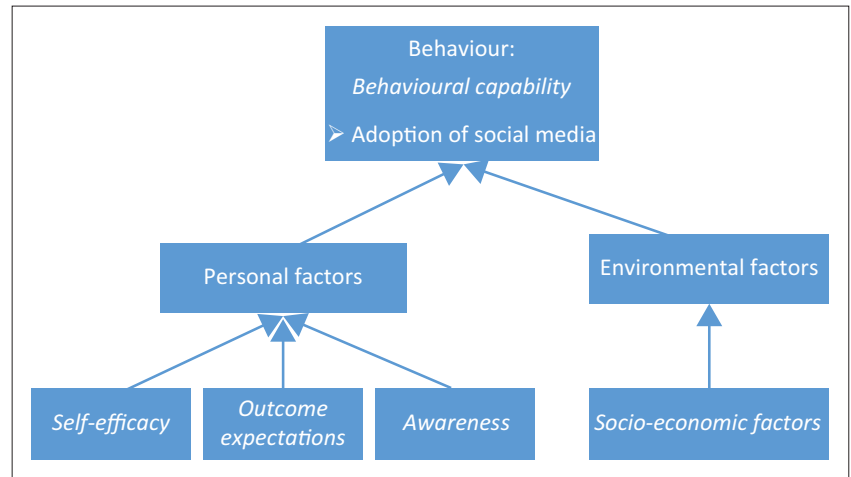

Source: Bandura, A., 1989, 'Social cognitive theory', in R. Vasta (ed.), Annals of child development: Six theories of child development, vol. 6, pp. 1-60, JAI Press, Greenwich, CT. FIGURE 1: The conceptual model.

individual. As outlined by Bandura (1989) in social cognitive theory, personal factors include biological properties of the organism, individual's expectation, beliefs and selfperceptions, whilst environmental factors encompass the physical and social environments. Personal and environmental factors as shown in the following model to address the issue of DD.

The constructs are explained as follows:

\section{Personal factors}

Personal factors include cognitive, affective and biological characteristics of the individual. Ramirez, Kulinna and Cothran (2012) stated that personal factors include knowledge, perceived self-efficacy and outcome expectations related to the behaviour adoption. Personal factors can be explained using sub-constructs: self-efficacy, awareness and outcome expectation:

Hypothesis 1: Personal factors will have a positive impact on adoption of social media to facilitate student learning in $\mathrm{HE}$ institutions.

\section{Self-efficacy}

Self-efficacy is defined as the belief in one's capabilities to achieve a goal or an outcome. Self-efficacy beliefs determine how people feel, think, motivate themselves and behave, and such beliefs produce these diverse effects through four major processes, which include cognitive, motivational, affective and selection processes (Friedman 1998):

Hypothesis 1(a): Self-efficacy will have a positive impact on students' personal factors.

\section{Awareness}

Awareness is the degree at which users are aware of and have knowledge of the new technology, and how it works. According to Rengert (2011), behavioural factors are influenced by knowledge and skills. If an individual has knowledge and skills or aware of an innovation, it becomes easier for the person to adopt:

Hypothesis 1b: Awareness will have a positive impact on students' personal factors. 


\section{Outcome expectations}

Outcome expectations are the beliefs about the consequences or outcomes of performing behaviour. These are based on the individual's belief regarding the behaviour-outcome relationship (Keller et al. 1999):

Hypothesis 1c: Outcome expectation will have a positive impact on students' personal factors.

\section{Environmental factors}

According to Anderson et al. (2010:22) in social cognitive theory, environmental factors directly influence individuals' self-efficacy to perform good behaviours. Cunningham et al. (2005:125) also emphasised that environmental factors are believed to directly influence self-efficacy, which, in turn, influences subsequent interests, choice of goals and actions:

Hypothesis 2: Environmental factors will have a positive impact on adoption of social media to facilitate student learning in HE institutions.

\section{Socio-economic factors}

Socio-economic factors are the social and economic experiences and realities that help to develop one's personality, attitudes and lifestyle (Chase 2017). According to Chase, socio-economic factors include education, income and occupation, place of residence and culture or ethnicity:

Hypothesis 2a: Socio-economic factors will have a positive impact on students' environmental factors.

Personal factors and environmental factors also have a reciprocal relationship, whereby personal factors have an impact on environmental factors, whilst environmental factors have an impact on personal factors.

\section{Materials and methods}

A quantitative study using a survey method was used to conduct the research study. Quantitative research necessitates the diminution of phenomena to arithmetical values in order to carry out statistical analysis (Gelo, Braakmann \& Benetka 2008). This research study collected quantitative data using a closed-ended questionnaire because it provides the researcher with numerical data (Zohrabi 2013). The sample population for this research study included 600 first-year students from a multi-campus university in South Africa. Probability and non-probability sampling methods were used for this study. Probability random sampling was used for the selection of participants because it ensures external validity and generalisability, and reduces the possibilities of sampling biases (Fox, Hunn \& Mathers 2007). Non-probability sampling was purposively used to select first-year students, and probability sampling was employed to select 300 first-year students randomly from each of the campuses. These two campuses were purposively selected because one is situated in an urban metropolitan city. Students who study there come from different backgrounds, and other campus, on the other hand, was selected because it is one of the distance campuses where majority of the students come from rural areas.

Applying the identified social cognitive theory factors and the DD elements, a questionnaire was constructed and used to collect the research data. According to Ilorah (2017), questionnaire is a data collection technique where respondents answer research questions by selecting their appropriate choices from given answers or supplying their own answers electronically or on a hard copy. They were hand delivered and later collected back. The hand-delivery method provides a high response rate, and the researcher has an opportunity to know who received the questionnaire and who did not receive them (Phellas, Bloch \& Seale 2012). IBM SPSS 24.0 was used for descriptive statistics and for testing the validity and reliability of data collected. Out of the 600 questionnaires distributed, 321 were found to be useful for analysis.

In order to design the survey questionnaire, the guidelines as provided by Babbie (2005) and Kumar (2011) were followed. Each construct was represented on the survey by multiple statement items. Some of the statements and questions were adapted from the study of Dewar et al. (2012) and were formulated to suit this study.

The questionnaire was structured as a multiple-choice closed statement item where participants were asked to select their level of agreement with each statement. Before distributing the questionnaire, they were given to two PhD students, three Master students and five first-year students to pretest to check for ambiguous statements, negative, double barrelled questions, errors, instruction clarity and duplicate items. The questionnaire was then restructured using the feedback from the pretest. The instrument was designed primarily to assess the impact of DD on the adoption of social media for learning using the constructs of social cognitive theory as in the conceptual model.

\section{Ethical considerations}

The necessary ethical clearance was obtained from Research Ethics Committee of Tshwane University of Technology with Ref \#: REC/2017/05/002. The study also ensured that participants' privacy and confidentiality were maintained, and all issues raised by them were respected and taken into consideration. The Research Ethics Committee had approved the questionnaire for this research study.

\section{Results}

The result revealed that majority of the participants (67.0\%) were from the rural-based campus and others (33.0\%) were from the urban-based campus. The result also showed that out of the 321 usable questionnaires, majority of the respondents were female (61.1\%) and others (38.9\%) were male. Most of the respondents were between the ages of 18-24 years (85.7\%), followed by age group 25-34 (14.3\%). 
The result also demonstrates that majority of the participants were from rural areas $(74.1 \%)$, as compared to urban areas (25.9\%). In terms of mobile ownership, the result showed that $70.1 \%$ of students own smartphones, $16.2 \%$ of them own tablets and only $13.7 \%$ own a cell phone without Internet connection. This means that $86.3 \%$ of students were able to access Internet from their phones. It also reveals that students in HE institutions are aware of social media usage, its technologies and qualities. Majority of the respondents (85.3\%) showed awareness of social media tools, and $84.7 \%$ of them highlighted that they were aware that social media can be used to facilitate learning. About $75.1 \%$ of the respondents indicated that they are aware of the fact that social media can help them to interact with their fellow students.

The results of correlation analysis show a positive relationship between awareness $(r=0.253 * *, p<0.01)$ and behavioural strategies, which means that the more the students are aware of social media usage, the more they intend to adopt it. The results of regression analysis also proved awareness (Beta $=0.213$, Sig. $=0.000$ ) as one of the main predictors of personal factors and, therefore, has an impact on adoption of social media for learning.

Most of the participants believed that if they had access to ICTs, such as computer and Internet, they would find it helpful to use social media for their studies. The analysis revealed that $75.7 \%$ of the respondents agreed that it was easy for them to learn using social media. On the other hand, $81.6 \%$ believed that they had the knowledge of using social media for their studies and $79.4 \%$ believed that they had the ability to use social media to support their learning studies. The results of correlation analysis revealed that more students believed that they had knowledge, ability and skills of using social media and intend to adopt social media for learning. The correlation showed a positive relationship between self-efficacy $\left(r=0.236^{* *}, p<0.01\right)$ and behavioural strategies.

The results of regression analysis revealed self-efficacy (Beta $=0.220$, Sig. $=0.000)$, showing that it has an impact on personal factors, which, in turn, impacts the adoption of social media for learning. The findings show that $68.0 \%$ of students responded that social media could help to improve their learning. On the other hand, $85.7 \%$ believed that it could help them interact with their classmates online, and $82.8 \%$ believed that social media could help them be updated with their course or subject. The correlation analysis results revealed that outcome expectations have no relationship ( $r=0.097, p>0.00)$ with behavioural strategies. Regression analysis also supported the correlation analysis results by showing that outcome expectations $($ Beta $=-0.053$, Sig. $=0.374)$ do not have an impact on adoption of social media for learning in HE institutions. From the analysis, although the participants agreed strongly on the benefits that social media can offer for learning, the result indicates that outcome expectation does not predict adoption.
The result also shows that out of the $46.1 \%$ of the participants who had access to computers at home, only $27.8 \%$ had computers with access to the Internet. In terms of public services, $36.5 \%$ of the students indicated that they had a public library where they could access computers connected to the Internet for free of charge.

In contrast, only $47.4 \%$ of students responded positively that they had an Internet cafe in their area where they could access pay-to-use Internet. The correlation analysis results revealed that there is a negative relationship between socioeconomic factors $(r=-0.045, p>0.00)$ and behavioural strategies. The results of regression analysis also supported the correlation analysis result by showing that socioeconomic factors (Beta $=-0.120$, Sig. $=0.030$ ) are not significant predictors in this study. This could be as a result of the finding that majority of the students had smartphones or Internet-enabled phones, which suggested that they could access social media from their phones. From the observation and preliminary exploration, it shows that students sell their books and skip meals in order to buy smartphones. Beger and Sinha (2012) earlier indicated that $72 \%$ of South African youth within the age group of 15-24 years own cell phones with Internet connection.

Four hypotheses were formulated and tested using a linear regression analysis approach by reverting each of the independent variable to a dependent variable - behavioural strategies. From the four hypotheses formulated, three are predicting personal factors, which, in turn, predict behavioural strategies; that is, awareness, intended to explain that selfefficacy and outcome expectations fall under personal factors from this study's conceptual model, and socio-economic factors are explained as environmental factors.

The findings of this research study prove that personal factors measured using awareness and self-efficacy are the main predictor of impact on adoption of social media for learning. Outcome expectations and socio-economic factors do not have a significant impact on adoption of social media.

Awareness (H1[a]) was supported. H1(a) stated that awareness has a positive impact on personal factors. Based on the result, many students responded that they are aware of social media. Correlation analysis results revealed that there is a positive relationship between awareness $\left(r=0.253^{* *}, p<0.01\right)$ and behavioural strategies. Regression analysis also proved that awareness is one of the main predictors of personal factors and indirectly has an impact on adoption of social media. Therefore, awareness proved to have an impact on personal factors, and hence, an impact on adoption of social media.

Self-efficacy $(\mathrm{H} 1[\mathrm{~b}])$ was supported. H1(b) stated that selfefficacy has a positive impact on students' personal factors. The outcome from the correlation analysis shows a positive relationship between self-efficacy $\left(r=0.236^{* *}, p<0.01\right)$ and behavioural strategies. Regression analysis also proved selfefficacy as one of the main predicators of personal factors, 
and hence, has an impact on adoption of social media for learning. This means that the more the students believed that they have abilities, knowledge and skills to use social media, the more they become interested in adopting social media for their studies.

Outcome expectations (H1[c]) was not supported. H1(c) stated that outcome expectations have a positive impact on students' personal factors. Correlation analysis results revealed a positive relationship between outcome expectations $(r=0.380 * *, p<0.01)$ and self-efficacy and between outcome expectations $(r=0.352 * *, p<0.01)$ and awareness. The results of regression analysis found outcome expectations $($ Beta $=-0.053$, Sig. $=0.374)$ to be not a significant predictor of impact on adoption of social media for learning. Therefore, outcome expectations were proven to have no impact on personal factors, and hence, no impact on the adoption of social media for learning.

Therefore, H1 was supported. H1 stated that personal factors have a positive impact on the adoption of social media to facilitate learning in $\mathrm{HE}$ institutions.

Socio-economic factors (H2[a]) was supported negatively. $\mathrm{H} 2$ (a) stated that socio-economic factors have a positive impact on environmental factors. Environmental factors are described as factors that help to clarify why challenging behaviours sometimes increase or decrease following changes in where a person lives or how they spend their days. The correlation analysis results revealed a negative relationship between socio-economic factors $(r=-0.045, p>$ 0.00 ) and behavioural strategy. The results of regression analysis supported the correlation analysis by proving that socio-economic factors (Beta $=-0.120$, Sig. $=0.030$ ) are not significant predictors of impact on the adoption of social media for learning. Students' physical surroundings, in addition to situations that they encounter, do not have an impact on their behaviour. Therefore, socio-economic factors do not have an impact on environmental factors, which means no impact on adoption of social media.

The result proved that $\mathrm{H} 2$ was not supported. $\mathrm{H} 2$ stated that environmental factors have a positive impact on adoption of social media to facilitate student learning in HE institutions.

\section{Discussion}

This research study was required to answer the following research problem: ' $[w]$ hy are many students in higher education institutions still not adopting social media technologies for their studies, despite the availability of social media and its benefits?'

The general conclusion of this study, based on the findings, is as follows:

- Majority of the students from HE institutions own smartphones and tablets, which they can use to access the Internet, and students believe that they have abilities and knowledge to using social media for their studies.
- The findings also revealed that majority of the students are aware of the fact that social media can be used to improve their learning.

- Variables, such as self-efficacy and awareness, have a significant impact on the adoption of social media, whereas outcome expectations and socio-economic factors were not found to have a significant impact on adoption of social media for learning.

- It was also found that majority of the students do not have access to computers and devices connected to the Internet at their homes. The findings also revealed that majority of the students do not find help on how to use computers at home. However, it was concluded from the analysed response from the participants that these social factors (low income, unemployment and low education levels) do not impact the adoption of social media for learning.

- The findings also show that majority of the students do not have public libraries in their areas where they can access Internet for free; the majority also indicated that there is no money at home that they can use to buy Internet session at Internet café. However, this does not impact the adoption of social media for learning. This can only be attributed to the high ownership of Internetenabled cell phones by students.

The major limitation of this study is that it was focused only on one university, which could limit the generalisation of findings, unlike if the findings compared two or more different universities. The study also focused on two campuses out of the seven campuses of Tshwane University of Technology. If more campuses were included, maybe the findings would have been different. Another limitation arising from this study was that the study focused only on three social media technologies. Maybe if more social media technologies were included, more information would have come to light.

It is recommended that future research in this field should cover at least two or more universities in a way, which will help to increase the generalisability of the findings, and studies on how ownership of computers and devices connected to the Internet, especially amongst students from disadvantaged backgrounds, can be promoted.

\section{Conclusion}

This research study investigated the impact of DD on adoption of social media for learning. The study reported the findings from the quantitative research study, where the data were collected from 600 first-year students of two campuses of a multi-campus university in South Africa. Only 321 of 440 questionnaires returned were found to be useful for analysis. The study proposed social cognitive theory in purpose of understanding the Socio-economic and Personal factors that have impact in the adoption of social media for learning. 
From the results analysed, DD factors that were found to have an impact on adoption of social media were identified. The conclusion drawn from demographic factors showed that majority of the students own phones with Internet capability. A lack of access to computers - and devices connected to the Internet - was found to have no impact on adoption of social media. All hypotheses were tested, and three hypotheses were supported and three were not supported. Self-efficacy and awareness were shown to have a significant impact on adoption of social media, whereas outcome expectations and socio-economic factors were found to have no significant impact on adoption of social media for learning.

\section{Acknowledgements}

The authors thank the first-year students of Tshwane University of Technology from Polokwane and Soshanguve campuses for participating in the study and answering the questionnaire and also their lecturers who helped the authors with the distributions of questionnaire during data collection.

\section{Competing interests}

The authors declare that they have no financial or personal relationships that may have inappropriately influenced them in writing this article.

\section{Authors' contributions}

M.I.M. conducted the research as part of MTech degree at Tshwane University of Technology under the supervision of S.N.M. and A.I.

\section{Funding information}

This research study received no specific grant from any funding agency in the public, commercial or not-for-profit sectors.

\section{Data availability}

The data that support the findings of this study are available on request from the corresponding author, M.I.M. The data are not publicly available as they consist of information that could compromise the privacy of research participants.

\section{Disclaimer}

The views and opinions expressed in this study are those of the authors and do not necessarily reflect the official policy or position of any affiliated agency of the authors.

\section{References}

Ali, A.H., 2011, 'The power of social media in developing nations: New tools for closing the global digital divide and beyond', Harvard Human Rights Journal 24, 185-219,
viewed 18 September 2017, from https://harvardhrj.com/wp-content/uploads/ viewed 18 September 2017, from
sites/14/2009/09/185-220.pdf.

Anderson, E.S., Winett, R.A., Wojcik, J.R. \& Williams, D.M., 2010, 'Social cognitive mediators of change in a group randomized nutrition and physical activity intervention: Social Support, self-efficacy, outcome expectations and selfintervention: Social Support, self-efficacy, outcome expectations and self-
regulation in the guide-to-health trial', Journal of Health Psychology 15(1), 21-32. regulation in the guide-to-health trial', Journal
https://doi.org/10.1177/1359105309342297
Arif, M. \& Kanwal, S., 2016, 'Adoption of social media technologies and their impact on students' academic performance: The only way for future survival of distance education students in Pakistan', Pakistan Journal of Information Management \& education students in Pakistan', Pakistan Journal of Information Manag
Libraries (PJIM\&L) 18(1), 25-36. https://doi.org/10.47657/2016181947

Attuquayefio, S., 2019, 'Development of a conceptual framework to support ICT adoption by Ghanaian higher education students', International Journal of Education and Development using Information and Communication Technology 15(4), 116-131.

Babbie, E., 2005, The basics of social research, Thomson Learning, Belmont, CA.

Bala, M., 2018, Use of ICT in higher education, Assistant Professor, Department of Mathematics, S.V. College, Aligarh Swaranjali Publication, Perth.

Bandura, A., 1986, Social foundations of thought and action: A social cognitive theory, Prentice-Hall, Inc., Englewood Cliffs, NJ.

Bandura, A., 1989, 'Social cognitive theory', in R. Vasta (ed.), Annals of child development: Six theories of child development, vol. 6, pp. 1-60, JAI Press, Greenwich, CT.

Barnard, Z. \& Van Der Merwe, D., 2015, 'Bridging the digital divide: Case study of the distribution of tablets to first years at the University of Johannesburg', Proceedings of Informing Science \& IT Education Conference (InSITE) 480-491, viewed 22 September 2017, from http://Proceedings.InformingScience.org/InSITE2015/ InSITE15p479-491Barnard1541.pdf.

Beger, G. \& Sinha, A., 2012, South African mobile generation. Study on South African young people on mobiles, pp. 1-47, viewed 25 August 2017, from https://www. unicef.org/csr/files/UNICEF_South_Africa_the_mobile_generation.pdf.

Broadbent, R. \& Papadopoulos, T., 2013, 'Bridging the digital divide - an Australian story', Behaviour \& Information Technology 32(1), 4-13. https://doi.org/10.1080/ 0144929X.2011.572186

Camerini, A.L., Schulz, P.J. \& Jeannet, A.-M., 2018, 'The social inequalities of internet access, its use, and the impact on children's academic performance', New Media \& Society 20(7), 2489-2508. https://doi.org/10.1177/1461444817725918

Chamberlin, L. \& Lehmann, K., 2011, 'Twitter in higher education', in C. Wankel (ed.), Educating educators with social media, vol. 1, pp. 375-391, Emerald Group Publishing Limited, Bingley.

Chase, M., 2017, Definition of socio-economic factors, viewed 22 August 2017, from http://www.ehow.co.uk/about_5370269_definition-socioeconomic-factors.html.

Chawinga, W., 2017, 'Taking social media to a university classroom: Teaching and learning using Twitter and blogs', International Journal of Educational Technology 14(3), 2-19. https://doi.org/10.1186/s41239-017-0041-6

Chetty, K., Qigui, L., Gcora, N., Josie, J., Wenwei, L. \& Fang, C., 2018, 'Bridging the digital divide: Measuring digital literacy', Economics: The Open-Access, OpenAssessment E-Journal 12(23), 1-20. https://doi.org/10.5018/economics-ejournal. ja.2018-23

Cruz-Jesus, F., Oliveira, T. \& Bacao, F., 2012, 'Digital divide across the European Union', Information \& Management 49(6), 278-291. https://doi.org/10.1016/j. im.2012.09.003

Cunningham, G.B., Bruening, J., Sartore, M.L., Sagas, M. \& Fink, J.S., 2005, 'The application of social cognitive career theory to sport and leisure career choices', Journal of Career Development 32(2), 122-138. https://doi. org/10.1177/0894845305279164

Davis, C.H., Deil-Amen, R., Rios-Aguilar, C. \& Canche, M.S., 2012, Social media in higher education: A literature review and research directions, pp. 1-30, The Center for the Study of Higher Education at The University of Arizona AND Claremont Graduate University, viewed 28 July 2017, from https://www. academia.edu/1220569/Social_Media_in_Higher_Education_A_Literature Review_and_Research_Directions.

Development support monitor, 2012, Paper series No. 1, African Monitor, viewed 22 August 2017, from http://www.africanmonitor.org/assets/files/Publications/ Rural\%20Infrastructure\%20In\%20Africa.pdf.

Dewar, D., Lubans, D., Plotnikoff, R. \& Morgan, P., 2012, 'Development and evaluation of social cognitive measures related to adolescent dietary behaviors', International Journal of Behavioral Nutrition and Physical Activity 9(36), 1-10. https://doi. Journal of Behavioral Nutrition
org/10.1186/1479-5868-9-36

Du Toit, J., 2015, 'Teacher training and usage of ICT in education', Background paper for ICT in education statistics, Paris: UNESCO Institute for Statistics, pp. 3-22, viewed n.d., from http://www.uis.unesco.org/StatisticalCapacityBuilding/ ICT-teacher\%20training-use_EN.pdf.

Esfijani, A. \& Zamani, B., 2020, 'Factors influencing teachers' utilisation of ICT: The role of in-service training courses and access', Research in Learning Technology 28(2020), 1-16. https://doi.org/10.25304/rlt.v28.2313

Fox, N., Hunn, A. \& Mathers, N., 2007, Sampling and Sample Size Calculation, pp. 2-41, The National Institute for Health Research (NIHR) Research Design Service (RDS) for the East Midlands / Yorkshire \& the Humber, Nottingham and Sheffield.

Friedman, S.S., 1998, Mappings: Feminism and the cultural geographies of encounter, Princeton University Press, Princeton, NJ.

Gemiya, A.G., 2020, 'Factors affecting the use of ICT services in Ethiopia: The case of Illubabor Zone - Oromia Reginal State', International Journal of Information and Communication Technology Education 16(1), 50-60. https://doi.org/10.4018/ IJICTE.2020010104

Gelo, O., Braakmann, D. \& Benetka, G., 2008, 'Quantitative and qualitative research: Beyond the debate', Integrative Psychological and Behavioral Science 42, 266-290. https://doi.org/10.1007/s12124-008-9078-3 
Gillwald, A., Mothobi, O. \& Rademan, B., 2018, The state of ICT in South Africa, researchlCTafrica, net viewed 25 October 2020, from https://researchictafrica. researchICTafrica.net, viewed 25 October 2020, from https://research
net/after-access-south-africa-state-of-ict-2017-south-africa-report_04/.

Gudmundsdottir, G., 2010, 'From digital divide to digital equity: Learners' ICT competence in four primary schools in Cape Town, South Africa', International Journal of Education and Development using Information and Communication Technology (IJEDICT) 6(2), 84-105.

Gündüz, H.B., 2010, 'Digital divide in Turkish primary schools: Sakarya sample', The Turkish Online Journal of Educational Technology 9(1), 43-53.

Haight, M., Quan-Haase, A. \& Corbett, B.A., 2014, 'Revisiting the digital divide in Canada: The impact of demographic factors on access to the internet, level of online activity, and social networking site usage', Information, Communication \& Society 17(4), 503-519. https://doi.org/10.1080/136911 $8 \mathrm{X} .2014 .891633$

Haryanti, S. \& Rusfian, E.Z., 2018, 'Government public relations and social media: Bridging the digital divide on people with social welfare problems', Jurnal Kebijakan dan Administrasi Publik (JKAP) [Journal of Public Policy and Administration] 22(2), 128-145. https://doi.org/10.22146/jkap.34602

Hassan, Z., Khoumbati, K.U.R., Bhatti, Z. \& Dahri, K., 2019, 'A conceptual framework development of the social media learning for undergraduate students of University of Sindh', University of Sindh Journal of Information and Communication Technology (USJICT) 3(4), 179-148.

Ilorah, A., 2017, 'A Mobile e-Healthcare readiness framework for rural South Africa', Doctor Technologiae Dissertation, Tshwane University of Technology, Faculty of ICT, pp. 1-349.

Ilorah, A.I., Sello, N., Mokwena, S.N. \& Ditsa, G.E.M., 2017, 'Issues and challenges of implementing mobile e-healthcare systems in South Africa', African Journal of Biomedical Research 20(3), 249-255.

Junco, R., Heibergert, G. \& Loken, E., 2011, 'The effect of Twitter on college studen engagement and grades', Journal of Computer Assisted Learning 27(2), 119-132. engagement and grades', Journal of Computer Assiste
https://doi.org/10.1111/j.1365-2729.2010.00387.x

Kausar, S. \& Awan, A.G., 2019, 'Impact of using social media on academic performance of students at graduate level: Evidence from Pakistan', Global Journal of Management, Social Sciences and Humanities 5(1), 116-142.

Keller, C., Fleury, J., Gregor-Holt, N. \& Thompson, T., 1999, 'Predictive ability of socia cognitive theory in exercise research: An integrated literature review', The Online Journal of Knowledge Synthesis for Nursing 6(2), viewed 14 September 2017, from https://pubmed.ncbi.nlm.nih.gov/12870090/.

Krish, C., Urvashi, A., Vidisha, M., Nozibele, G. \& Jaya, J., 2018, 'Bridging the digital divide in the G20: Skills for the new age', Economics: The Open-Access, Open-Assessmen E-Journal 12(24), 1-20. https://doi.org/10.5018/economics-ejournal.ja.2018-24

Kumar, R., 2011, Research methodology: A step by step guide for beginners, 3rd edn., Sage, London.

Li, Y. \& Ranieri, M., 2013, 'Educational and social correlates of the digital divide for rural and urban children: A study on primary school students in a provincial city of China', Computers \& Education 60(1), 197-209. https://doi.org/10.1016/j. compedu.2012.08.001

Liu, Y., 2010, 'Social media tools as a learning resource', Journal of Educational Technology Development and Exchange 3(1), 101-114. https://doi.org/10.18785/ jetde.0301.08

Moghavvemi, S., Sulaiman, A., Jaafar, N.I. \& Kasem, N., 2018, 'Social media as a complementary learning tool for teaching and learning: The case of YouTube', The International Encyclopedia of Media Effects 16(1), 1-11. https://doi.org/10.1016/j. ijme.2017.12.001
Mokwena, S.N. \& Hlebela, C., 2018, 'Factors affecting the adoption of software as a service in South African small medium enterprises', in 2018 Open Innovations Conference (OI), Johannesburg, South Africa, 3-5 October 2018, pp. 1-6. https:// Conference (OI), Johannesburg, South
doi.org/10.1109/OI.2018.8535714

Naidoo, S. \& Raju, J., 2012, 'Impact of the digital divide on information literacy training in a higher education context', South African Journal of Libraries and Information Science 78(1), 34-44. https://doi.org/10.7553/78-1-46

Organization for Economic Co-operation and Development, 2001, Understanding digital divide, Organization for Economic Co-operation and Development, Paris, viewed 23 June 2017, from http://www.oecd.org//dac/ictcd/docs/otherdocs/ OtherOECD_understanding_DD.pdf.

Perrin, A., 2015, Social media usage: 2005-2015, pp. 1-11, Pew Research Center, viewed 26 June 2017, from http://www.pewinternet.org/2015/10/08/2015/ Social-Networking-Usage-2005-2015/.

Phellas, C., Bloch, A. \& Seale, C., 2012, Structured Methods: Interview, Questionnaires and Observations, SAGE Publication, London.

Prescott, J., Wilson, S. \& Becket, G., 2013, 'Facebook use in the learning environment: Do students want this?', Learning, Media and Technology 38(3), 345-350. https:// doi.org/10.1080/17439884.2013.788027

Ramirez, E., Kulinna, P.H. \& Cothran, D., 2012, 'Constructs of physical activity behaviour in children: The usefulness of social cognitive theory', Psychology of Sport and Exercise 13(3), 303-310. https://doi.org/10.1016/j.psychsport.2011.11.007

Rengert, J., 2011, 'Development and evaluation of a social cognitive theory-based exercise intervention in firefighters: 5-ALARM fitness program', Dissertation presented in partial fulfillment of the requirements for the degreertor presented in partor of 15 August 2017, from https://etd.ohiolink.edu/!etd.send file?accession=osu130 15 August 2017, from https:
6158455\&disposition=inline.

Singh, A., 2018, 'Facebook, WhatsApp, and Twitter: Journey towards education' Jurnal Sosial dan Humaniora [Journal of Social Sciences and Humanities] 8(2), 139-149. https://doi.org/10.31940/soshum.v8i2.987

Smith, T.M., 2015, The digital divide and its effect on student learning, Department of Educational Leadership and Human Development University of Central Missouri, August 2015, pp. 1-25, viewed 22 August 2017, from https://www. semanticscholar.org/paper/the-digital-divide-and-its-effect-on-student-Smith/ d582c93e28aea3c102674c841acf191884534c12.

Soh, C.-H., Yan, Y.L., Ong, T.S. \& Teh, B.H., 2012, 'Digital divide amongst urban youths in Malaysia - Myth or reality?', Asian Social Science 8(15), 75-85. https://doi. org/10.5539/ass.v8n15p75

Sparks, C., 2013, 'What is the "Digital Divide" and why is it important?', Journal of the European Institute for Communication and Culture 20(2), 27-46. https://doi.org/ 10.1080/13183222.2013.11009113

Tiryakioglu, F. \& Erzurum, F., 2011, 'Use of social networks as an education tool', Contemporary Educational Technology 2(2), 135-150. https://doi.org/10.30935/ cedtech/6048

Van Dijk, J.A.G.M., 2017, 'Digital divide: Impact of access', The International Encyclopedia of Media Effects 1-11 (2017). https://doi. org/10.1002/9781118783764.wbieme0043

Vekiri, I., 2010, 'Socio-economic differences in elementary students' ICT beliefs and out-of-school experiences', Computers \& Education 54(4), 941-950. https://doi. out-of-school experiences', Computers
org/10.1016/j.compedu.2009.09.029

Zohrabi, M., 2013, 'Mixed method research: Instruments, validity, reliability and reporting findings', Theory and Practice in Lanquage Studies 3(2), 254-262. https://doi.org/10.4304/tpls.3.2.254-262 